\title{
Article
}

\section{G Mobile Phone Network Introduction in Colombia}

\author{
Dora Cama-Pinto ${ }^{1, *}{ }^{\mathbb{D}}$, Miguel Damas ${ }^{1}{ }^{\mathbb{D}}$, Juan Antonio Holgado-Terriza ${ }^{2} \mathbb{D}$, Francisco Gómez-Mula ${ }^{1}$, \\ Andrés Camilo Calderin-Curtidor ${ }^{3}$, Juan Martínez-Lao ${ }^{4}$ and Alejandro Cama-Pinto ${ }^{3, *(\mathbb{D}}$
}

1 Department of Computer Architecture and Technology, University of Granada, 18071 Granada, Spain; mdamas@ugr.es (M.D.); frgomez@ugr.es (F.G.-M.)

2 Department of Software Engineering, University of Granada, 18071 Granada, Spain; jholgado@ugr.es

3 Faculty of Engineering, Universidad de la Costa, 080002 Barranquilla, Atlantico, Colombia; acalderi2@cuc.edu.co

4 Department Engineering, University of Almeria, 04120 Almería, Spain; jml357@ual.es

* Correspondence: doracamapinto@correo.ugr.es (D.C.-P.); acama1@cuc.edu.co (A.C.-P.); Tel.: +57-5-3225498 (A.C.-P.)

Citation: Cama-Pinto, D.; Damas, M.; Holgado-Terriza, J.A.; Gómez-Mula,

F.; Calderin-Curtidor, A.C.;

Martínez-Lao, J.; Cama-Pinto, A. 5G Mobile Phone Network Introduction in Colombia. Electronics 2021, 10, 922. https://doi.org/10.3390/

electronics10080922

Academic Editor: Paulo Monteiro

Received: 3 February 2021

Accepted: 6 April 2021

Published: 13 April 2021

Publisher's Note: MDPI stays neutral with regard to jurisdictional claims in published maps and institutional affiliations.

Copyright: (c) 2021 by the authors. Licensee MDPI, Basel, Switzerland. This article is an open access article distributed under the terms and conditions of the Creative Commons Attribution (CC BY) license (https:// creativecommons.org/licenses/by/ $4.0 /)$.

\begin{abstract}
The deployment of the 5G mobile network is currently booming, offering commercially available services that improve network performance metrics by minimizing network latency in countries such as the USA, China, and Korea. However, many countries around the world are still in the pilot phase promoted and regulated by government agencies. This is the case in Colombia, where the assignment of the first $5 \mathrm{G}$ band is planned for the third quarter of 2021. By analyzing the results of the pilot phase and the roadmap of the Colombian Ministry of Information and Communication Technologies (MinTIC), we can determine the main issues, which contribute to the deployment of $5 \mathrm{G}$ mobile technology as well as the plans to achieve a $5 \mathrm{G}$ stand-alone network from $4 \mathrm{G}$ networks. This is applicable to other countries in Latin America and the world. Then, our objective is to synthesize and share the most important concepts of 5G mobile technology such as the MIMO (multiple input/multiple output) antenna, RAN (Radio Access Network), C-RAN (Centralised-RAN), and frequency bands, and evaluate the current stage of its introduction in Colombia.
\end{abstract}

Keywords: 5G; massive MIMO; MIMO; 5G Colombia; O-RAN; 5G trial; mm-W; stand-alone; 5G deployment; 5G Latin America

\section{Introduction}

In recent years, the explosive growth in the volume of communications data has exhausted the possibilities of current $4 \mathrm{G}$ mobile communications systems. Wireless data traffic is predicted to be more than 131 exabytes per month by the end of 2024, with more than $90 \%$ of wireless data traffic coming from cell phones. With the emergence of fifth generation (5G) mobile networks, network performance is improved to between $100 \times$ and $1000 \times$ as compared to existing technologies [1]. This is achieved by increasing spectral efficiency that provides massive connectivity, higher transmission speeds, shorter latency, and lower energy consumption [2]. It enables cloud-based applications, increasing the prospects for emerging technologies such as virtual reality (VR), smart cities, and autonomous car applications that adapt to the rapid evolution of the Internet of Things (IoT) and machineto-machine (M2M) communication [3-6]. Meanwhile, software-driven network integration (SDN) and network functions virtualisation (NFV) are considered effective solutions in the optimal performance of $5 \mathrm{G}$ network functionality with high scalability. They run on a cloud-based architecture that leverages the $5 \mathrm{G}$ core network architecture $(5 \mathrm{G}-\mathrm{CN})$ model to provide versatile network traffic management with distributed multi-controller architecture delivering a wide range of services [7].

The aim of our work is to show the relationship between the $5 \mathrm{G}$ mobile network and the multiple input/multiple output (MIMO) systems, the millimeter wave (mm-W), the frequencies from $30 \mathrm{GHz}$ up to $300 \mathrm{GHz}$, and the Sub- $6 \mathrm{GHz}$ bands, describing their 
main advantages, challenges, and supporting technology that allows us to achieve higher data transfer rates when compared to previous mobile networks based on $4 \mathrm{G}$. The original document supporting the understanding of this topic was taken from a systematic search and review of the Scopus database. In addition, information has been gathered from the official websites and documents of the Colombian Ministry of Information and Communication Technologies, the National Spectrum Agency of Colombia (ANE), the Global System for Mobile Communications (GSM Association), the Global mobile Suppliers Association (GSA), and the mobile operators, which will manage 5G mobile networks. The Government resolutions have been integrated in order to reveal the steps that the Colombian government is taking to implement the 5G mobile telephone network and the current status of its deployment in Colombia.

\section{Background}

In the next era of 5G (fifth generation) mobile communication, antenna designs for mobile terminals and base stations with higher transmission speeds, lower latency, and higher access speeds are being developed, which have absolute advantages over $4 \mathrm{G}$ (fourth generation) networks [8] and predecessors (Table 1).

Table 1. Evolution of mobile networks.

\begin{tabular}{cccccc}
\hline & 1G & 2G & 3G & 4G & 5G \\
\hline $\begin{array}{c}\text { Approximate date } \\
\text { of implementation }\end{array}$ & $1980 \mathrm{~s}$ & $1990 \mathrm{~s}$ & $2000 \mathrm{~s}$ & $2010 \mathrm{~s}$ & $2020 \mathrm{~s}$ \\
\hline $\begin{array}{c}\text { Theoretical } \\
\text { download speed }\end{array}$ & $2 \mathrm{kbps}$ & $384 \mathrm{kbps}$ & $56 \mathrm{Mbps}$ & $1 \mathrm{Gbps}$ & $10 \mathrm{Gbps}$ \\
\hline Latency & N/A & $629 \mathrm{~ms}$ & $212 \mathrm{~ms}$ & $60-98 \mathrm{~ms}$ & $<1 \mathrm{~ms}$ \\
\hline
\end{tabular}

In the near future, the aggregate data rate in $5 \mathrm{G}$ wireless communication systems is expected to be 1000 times faster than $4 \mathrm{G}$ with higher wireless link reliability. One of the main factors in achieving this is through MIMO antennas. Unlike $2 \mathrm{G}, 3 \mathrm{G}$, and $4 \mathrm{G}$ systems, where 2 and 4 element MIMO antennas have been used in the mobile terminal, the $5 \mathrm{G}$ system requires a larger number of MIMO antenna elements to achieve the expected speed [9].

5G new radius (NR) systems are based on OFDM (Orthogonal Frequency Division Multiplexing) modulation, and each of its sub-carriers is modulated with the binary phase shift keying (PSK) scheme, the quadrature PSK scheme (QPSK), 16-quadrature (16-QAM), 64-QAM, or 256-QAM amplitude modulation [10]. In addition, the flexibility of 5G NR allows support of multiple subcarrier separations, ranging from 15 to $240 \mathrm{kHz}$, depending on the deployment scenario and application [11]. The initial 5G standard launch by 3GPP (3rd Generation Partnership Project) specifies three different usage scenarios depending on the applications: (i) massive communications between machines (mMTC), designed to communicate one million devices per square kilometer, (ii) enhanced mobile broadband (eMBB) featuring maximum download speeds of $10 \mathrm{Gbps}$, a reliable user experience data rate of $100 \mathrm{Mbps}$ in urban areas, with a user plane latency of $4 \mathrm{~ms}$, and (iii) ultrareliable low-latency communications (URLCC) ensuring less than $1 \mathrm{~ms}$ latency, very high availability/reliability, and security for support services, such as autonomous vehicles and mobile healthcare [12]. The summary of typical 5G application scenarios is outlined in Table 2 and Figure 1 where they include: massive machine type communications (mMTC) for connecting large numbers of devices to a $5 \mathrm{G}$ network that can reach 1 million $/ \mathrm{km}^{2}$, making it possible to develop smart homes, smart buildings, and smart cities. In addition, in Figure 1, we have the enhanced mobile broadband (eMBB) as well as ultra-reliable and low-latency communications (uRLLC) $[13,14]$. 
Table 2. Typical 5G mobile technology application scenarios.

\begin{tabular}{ccc}
\hline $\begin{array}{c}\text { Massive Machine Type } \\
\text { Communications (mMTC) }\end{array}$ & $\begin{array}{c}\text { Enhanced Mobile } \\
\text { Broadband (eMBB) }\end{array}$ & $\begin{array}{c}\text { Ultra-Reliable, Low-Latency } \\
\text { Communications (URLLC) }\end{array}$ \\
\hline $\begin{array}{c}\text { IoT, asset tracking, smart } \\
\text { agriculture, smart cities, } \\
\text { energy control, smart homes, } \\
\text { and remote monitoring. }\end{array}$ & $\begin{array}{c}\text { Better quality broadband for } \\
\text { both indoor and outdoor use, } \\
\text { virtual, and augmented } \\
\text { reality. }\end{array}$ & $\begin{array}{c}\text { Autonomous vehicles, } \\
\text { intelligent electrical networks, } \\
\text { remote patient monitoring, } \\
\text { and telehealth and industrial } \\
\text { automation services. }\end{array}$ \\
\hline
\end{tabular}

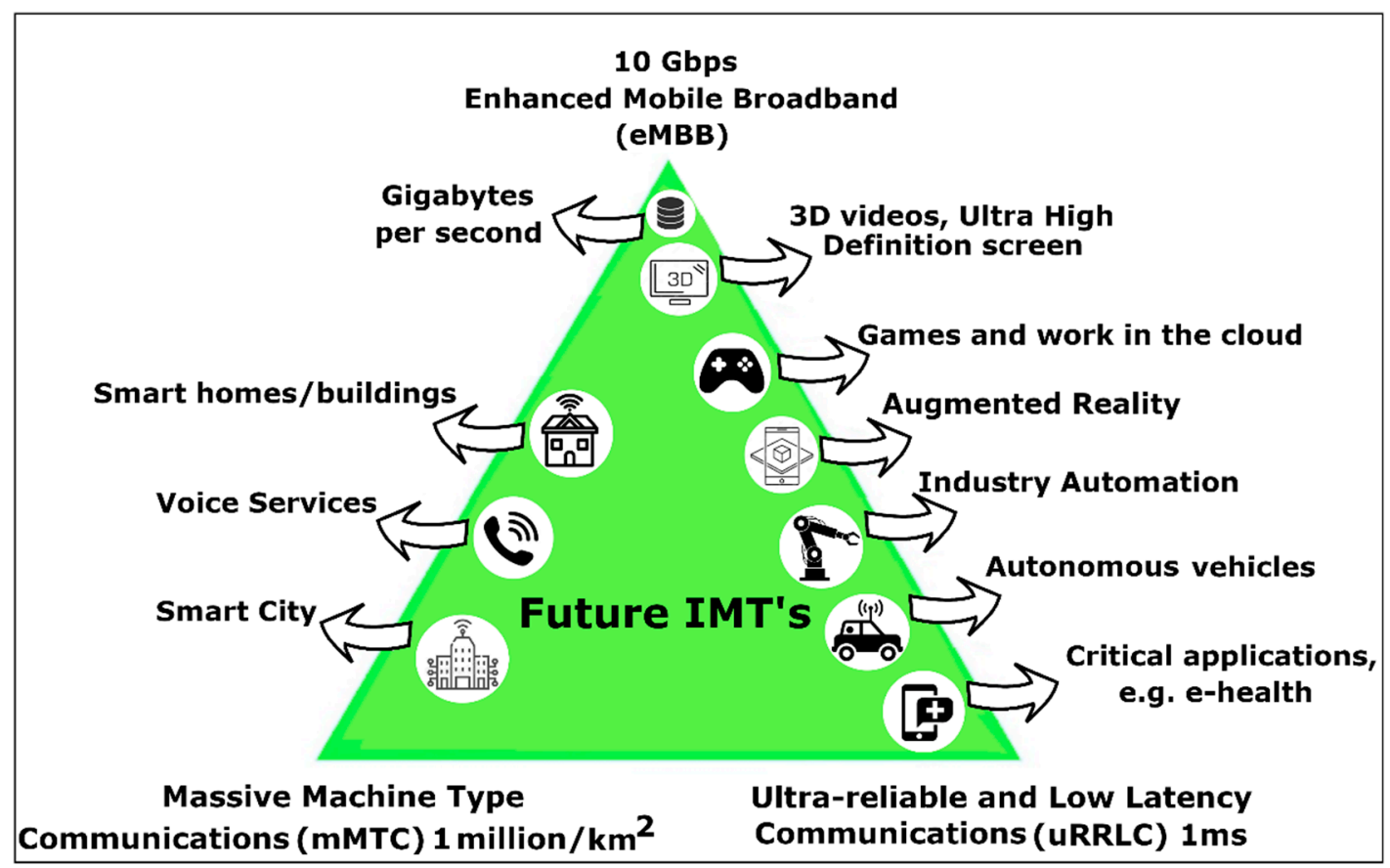

Figure 1. International Mobile Telecommunications (IMT) future for the typical application scenarios of 5G communication technology $[15,16]$.

\section{Frequency Bands in $5 \mathrm{G}$}

One of the bands for $5 \mathrm{G}$ network coverage is the Sub-6 GHz, which uses a macro cell base for nationwide deployment with a balance between a high transmission rate and a short-latency for end-users [11,17]. The Sub-6 GHz band mainly includes spectrum from the long-term evolution (LTE) bands 42, 43 (3.3 3.8 GHz), and 46 (5150-5925 MHz) [18,19]. The wavelength at $3500 \mathrm{MHz}$ is $86 \mathrm{~mm}$ in free space, which is favorable for deploying several antennas on the mobile terminal [20].

Frequency bands Sub-6 GHz are very crowded and have limited bandwidth available. Therefore, to meet the requirements of $5 \mathrm{G}$ in high-performance data transfer, providing an ultra-high-speed mobile broadband several $\mathrm{mm}-\mathrm{W}$ frequency bands have been proposed and approved in most developed countries. This includes $(24 \mathrm{GHz}$ to $29.5 \mathrm{GHz}),(37 \mathrm{GHz}$ to $42.5 \mathrm{GHz}$ ), (47.2 GHz to $48.2 \mathrm{GHz}$ ), and (64 to $71 \mathrm{GHz}$ ) [21] with 57 to $66 \mathrm{GHz}$ not requiring a global license [12]. One of the challenges for the use of $\mathrm{mm}-\mathrm{W}$ in $5 \mathrm{G}$ is the design of low-cost, energy-efficient, high-gain broadband antennas capable of overcoming propagation losses [22]. Antennas operating at $\mathrm{mm}-\mathrm{W}$ are mainly located along the side edge of the mobile device [23].

\section{Advantages and Disadvantages in Frequency Band mm-W and Sub-6 GHz in 5G}

Millimeter waves (mm-W) allow for high bandwidth [12], achieving a low latency and high data rate network [1]. However, its major disadvantage is its limited range without line 
of sight (NOS), poor diffraction capability, loss of surface waves, metallic losses [24], and path loss, all due to the high frequency, short wavelength being susceptible to atmospheric absorption, body absorption, and environmental blockage, such as raindrops, snow, and sand $[1,6]$. It is considered to implement dense networks of small cells with a large number of antennas (MIMO) to counteract the effects of the mm-W channel [25] by improving the coverage capacity through spatial multiplexing. Since small cells have a reduced effective coverage, their deployment can be multiplied in a given area, thus, increasing the number of devices connected to the network as well as raising data speeds per user. Despite this, small cells have difficulty in supporting multiple operators and accommodating various services, e.g., 3G, LTE, 5G, etc. with each mobile operator needing to implement and manage its own individual base station [12]. Table 3 summarizes the advantages and disadvantages of the frequency bands in 5G.

Table 3. Advantage and disadvantage in 5G band frequency [26].

\begin{tabular}{|c|c|c|}
\hline Band Frequency & Advantage & Disadvantage \\
\hline$<1 \mathrm{GHz}$ & $\begin{array}{l}\text { Greater coverage than higher } \\
\text { frequencies }(1 \mathrm{GHz}-6 \mathrm{GHz}),(\mathrm{mm}-\mathrm{W} \\
\text { bands up to } 66 \mathrm{GHz})\end{array}$ & $\begin{array}{l}\text { Lower channel capacity than other } \\
\text { frequencies }(1 \mathrm{GHz}-6 \mathrm{GHz}),(\mathrm{mm}-\mathrm{W} \\
\text { bands up to } 66 \mathrm{GHz})\end{array}$ \\
\hline $1 \mathrm{GHz}-6 \mathrm{GHz}$ & $\begin{array}{c}\text { Balanced combination of coverage } \\
\text { and channel capacity for } 5 \mathrm{G} \text { services } \\
\text { drives the first wave of } 5 \mathrm{G} \\
\text { deployments }\end{array}$ & $\begin{array}{l}\text { There are other mobile bands in the } 1 \text { to } \\
6 \mathrm{GHz} \text { range, currently used for } 3 \mathrm{G} \text { and } \\
4 \mathrm{G} \text { services, which could be gradually } \\
\text { reallocated for their use in } 5 \mathrm{G} \text {. }\end{array}$ \\
\hline$>6 \mathrm{GHz}$ & $\begin{array}{l}\text { Lower coverage than other } \\
\text { frequencies ( } 1 \mathrm{GHz}-6 \mathrm{GHz} \text { ) and } \\
\text { (mm-W bands up to } 66 \mathrm{GHz}) \\
\text { Supports ultra-fast mobile broadband } \\
\text { speeds envisioned for } 5 \mathrm{G} \text { technology } \\
\text { Will include unlicensed mobile bands }\end{array}$ & $\begin{array}{l}\text { Higher data rate than other } \\
\text { frequencies }(1 \mathrm{GHz}-6 \mathrm{GHz}),(\mathrm{mm}-\mathrm{W} \\
\text { bands up to } 66 \mathrm{GHz})\end{array}$ \\
\hline
\end{tabular}

\section{MIMO Systems}

Modern wireless communication systems must evolve to support a growing number of subscribers, all of whom are requesting services at the same time. This trend encourages the widespread application of multiple input/multiple output (MIMO) systems. In fact, MIMO techniques can increase data rates, service area coverage, and communication reliability without the need for additional radio frequencies [17]. In other words, MIMO technology can transmit more data with the help of multiple antennas on both the transmitter and receiver sides. MIMO makes use of the multipath phenomenon, in which data are received at the receiver several times with a certain time delay. MIMO performance is measured using envelope cross-correlation (ECC) between the different antennas. The goal of MIMO is to maximize channel capacity by reducing ECC [23]. Additionally, through the use of MIMO technology, multiple independent channels can be achieved in the original spectrum by the diversity method, and multipath fading can be reduced to improve the data rate [27]. In summary, MIMO systems with multiple antenna units on both the transmitter and receiver sides can take advantage of multipath components sufficiently to improve the performance of wireless systems.

It is a difficult task to achieve a desirable isolation of each antenna element of the MIMO system within a compact size at future 5G terminals, with mutual coupling of the adjacent antenna, especially for dual-band arrays, being one of the urgent difficulties to overcome $[28,29]$.

\subsection{Comparison of MIMO in $5 G$ vs. $4 G$}

$2 \times 2$ MIMO systems are successfully used for $4 \mathrm{G}$ mobile networks, and a large number of antenna elements are added for 5G communications. Several types of antennas have recently been proposed for 5G MIMO smartphones. Cell phones that operate with several 5G MIMO antennas at frequencies Sub-6 GHz must be accommodated in a limited size environment and coexist with the frequency antennas used by previous generations. The 
scheme of 5G MIMO antennas for smartphones is to have four or eight antenna elements in separate regions of the antenna itself where isolation is ensured by the distance between the elements obtaining low mutual coupling on unrelated channels. This is a difficult task for space limited smart phones. For this reason, the locations for the $3500 \mathrm{MHz} 5 \mathrm{G}$ band antenna on the mobiles is along the two long edges of the chassis ground, as the 4Gs usually occupy the space along the short edges. For example, some $4 \mathrm{G}$ services like Long Term Evolution (LTE) and GSM 850/900 have the primary antenna size of $45 \times 15 \mathrm{~mm}$ while the $5 \mathrm{G}$ auxiliary antenna size is $19 \times 15 \mathrm{~mm}[27,30]$.

\subsection{MIMO and $5 G$}

Since spectrum resources are valuable and limited, the fifth generation of mobile communications commonly known as $5 \mathrm{G}$ new radio (NR) improves spectrum efficiency by increasing communication channel capacity. It relies heavily on the use of MIMO antennas in mobile terminals, demonstrating multipath propagation with a higher data rate and link reliability, which are the main features of 5G. MIMO, with multiple transmittances receive antennas builds of huge information flows, thus, improving the channel capacity along with the advantages of high data rates and performance within the Gigabit/sec range without the need for power, bandwidth expenditure, or additional retransmission devices, while operating at frequencies of Sub-6 GHz [31]. On the other hand, MIMO antennas work better when they fully utilize a rich dispersion environment. Many studies show that MIMO antennas at relay nodes play an important role at $5 \mathrm{G}$ by providing extended coverage at cell edges as well as for indoor applications, even though they require high bandwidth and high gain to reduce atmospheric disturbances at millimeter frequencies $[4,10,18]$.

\subsection{Massive $M I M O$ and $5 G$}

The 5G network helps increase the number of applications that make use of artificial intelligence and mobile computing because they require higher wireless data speeds. In 5G NR, this is achieved by adopting massive MIMO and carrier aggregation (CA) with a wide channel bandwidth (BW) of up to $200 \mathrm{MHz}$ [32]. The concept of traditional MIMO is taken to another level, moving from tens to hundreds or thousands of antennas at the base station (BS) by serving a large number of autonomous terminals [33] with the goal of increasing antenna gains through appropriate fairly narrow beam-forming techniques, such as through accurate channel status information (CSI) [5]. Massive MIMO is a wireless physical layer technology [33]. Gives interference robustness, low latency, and security [3] by improving power output and system spectral efficiency [5] as a result of spatial multiplexing and providing uniform quality of service in different environments, especially in urban and suburban areas, while complementing or even replacing the process of densification of the ultra-network [25] able to support a large number of users [34]. Massive MIMO has good affinity with $\mathrm{mm}-\mathrm{W}$ communications because the antenna gains compensate for the propagation loss inherent in the VHF (Very High Frequency) band [6]. The massive antenna at base stations can be deployed in co-located or distributed configurations. In co-located massive MIMO, all antennas are located in a compact area and have the advantage of low backhaul requirements. In contrast to distributed massive MIMO systems, the antennas are distributed over a large area, offering a much higher coverage probability than co-located massive MIMO (mMIMO), at the expense of higher backhaul requirements [35]. Although the ideal bands for mMIMO are the millimetre bands (frequencies from $30 \mathrm{GHz}$ upwards) [36], the MinTIC only plans to auction up to the $3.5 \mathrm{GHz}$ band for the time being [37].

\section{Radio Access Network (RAN) in 5G}

The radio access network (RAN) architectures that have been mainly deployed for 5G are the C-RAN, which stands for centralised, clean, cloud, and collaborative RAN, and the distributed RAN (D-RAN). This latter one is the classic deployment most used on mobile networks today [38-40]. 
In distributed RAN architecture (D-RAN) places, all baseband units (BBUs) and remote radio heads (RRHs) at each cell site [41] communicating between them with the common public radio interface (CPRI) and its data exchange between the BBU and the core is over the backhaul, as shown in Figure 2a.

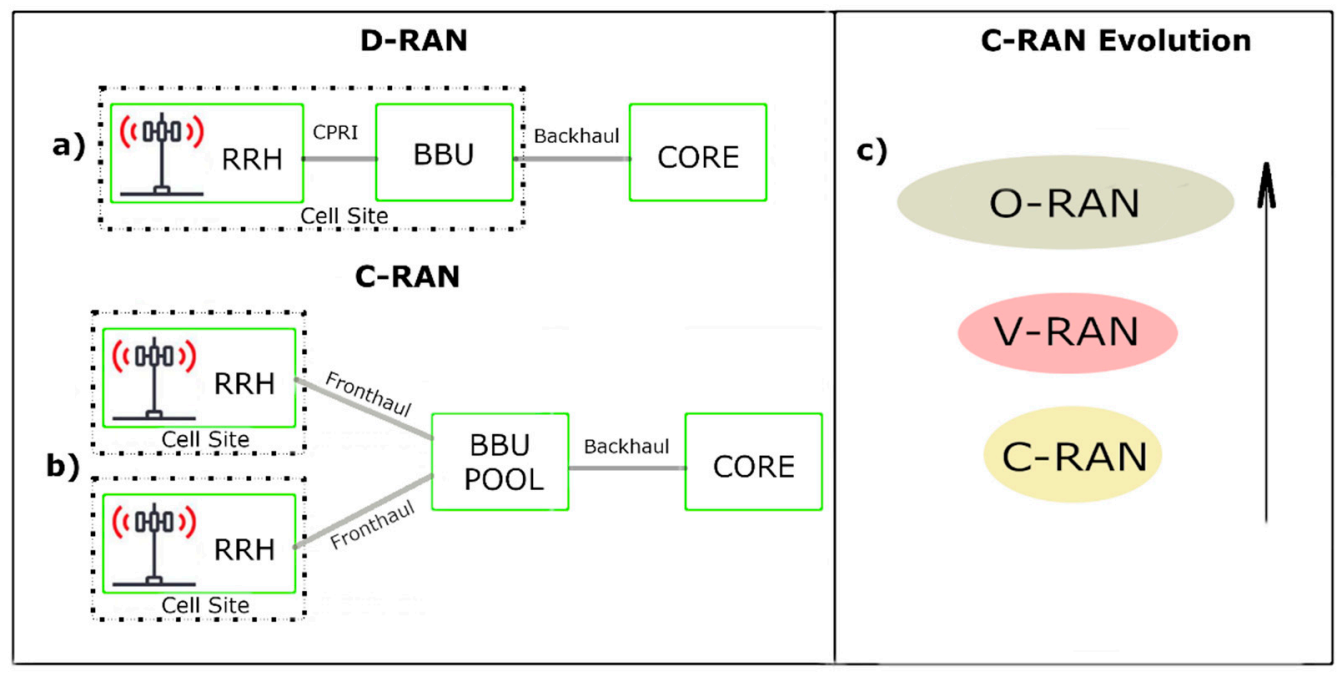

Figure 2. Scheme for: (a) Distributed-Radio Access Network (D-RAN) architecture. (b) Centralized Radio Access Network (C-RAN) architecture. (c) C-RAN evolution to V-RAN and O-RAN.

Likewise, in C-RAN, proposed by the China Mobile Research Institute, most of the RAN functionalities are centralised in a resource pool consisting of BBUs. C-RAN split Base Station (BS) to BBUs and remote radio heads. That is, it moves the BBU to a high-performance hosting datacenter with DSP (Digital Signal Processor). The fronthaul transport network provides high-bandwidth optical fibre linking between the BBU to the RRHs [42]. The RRH, containing the local oscillator, transforms the digital signal into an analog signal for transmission $[43,44]$ (see Figure $2 b$ ).

C-RAN has evolved to novel Virtual RAN (V-RAN) and Open RAN (O-RAN) [45]. On the one hand, V-RAN virtualizes BBUs in vBBUs deployed on multiple NFV platforms on standard $\times 86$ hardware [46] and grouped in centralized data centers, while RRHs continue to be located at their respective base stations [40]. As we can see in the Figure 2c) a key element of O-RAN is V-RAN [47]. O-RAN applies principles of openness through standardized and open interfaces and intelligence using artificial intelligence and machine learning to automate operational network functions [45,48].

\section{5G Deployment Architecture Options from LTE (4G)}

There are two approaches to deploy the $5 \mathrm{G}$ mobile network from LTE (4G). The SA (StandAlone) comprises architectures of 5G radio access without any interaction with an existing 4G core, while NSA (Non-StandAlone) comprise architectures that provide 5G built over an existing $4 \mathrm{G}$ network. Service providers who want to implement $5 \mathrm{G}$ speeds as soon as possible will start with NSA 5G networks aided by existing 4G infrastructure. This allows us to amortize the $4 \mathrm{G}$ core networks. Once $5 \mathrm{G}$ coverage may be established widely, then StandAlone 5G will be implemented [49].

The NSA option 3 family does not require 5G Core and provides dual connectivity supporting legacy $4 \mathrm{G}$ devices and the $5 \mathrm{G}$ devices [50,51], being a crucial feature connect to gNB ( $5 \mathrm{G}$ base station) and the eNB ( $4 \mathrm{G}$ base station) wirelessly with the user equipment (UE) [52]. It is composed for the master node (eNB) and the secondary node (gNB) and the RAN is connected to the 4G Core (Evolved Packet Core-EPC) [51,53]. Specifically, in the control plane Option $3 \mathrm{x}$, the eNB is connected to the EPC, and the gNB operates with the eNB. With regard to user plane traffic, EPC can transmit/receive it to/from both the 
$\mathrm{eNB}$ and the gNB. The gNB can steer the received user plane traffic toward the UE directly wirelessly or indirectly through the eNB [51].

\section{5G Network Mobile Deployment in Colombia}

Colombia adopts the technology neutrality scheme, meaning that, although the spectrum orientation is for specific services, the government does not specify what type of technology has to be used in these services (4G or $5 \mathrm{G}$ ). To improve the quality of service, it must acquire more spectrum because it only has $30 \%$ of the spectrum recommended by the Organization for Economic Cooperation and Development (OECD). Therefore, prioritizing the auction of spectrum to connect $70 \%$ of Colombians by 2022 and bring Colombia to 5G is the government's effort today.

\subsection{Road Map of Colombia Government}

The schedule outlined by the MinTIC for the first quarter of 2019 and third quarter of 2021 is described in Table 4, according to Reference [54]. During the fourth quarter of 2019 (Q4-2019), MinTIC prepared and published the plan for the adoption of 5G technology. In the second quarter of the year 2020 (Q2-2020), the frequency bands and spectrum requirements in 5G were identified. By the third quarter of 2020 (Q3-2020), MinTIC will promote the development of $5 \mathrm{G}$ applications. Regulatory adjustments will be made in the last quarter of 2020 (Q4-2020). Subsequently, by the second quarter of 2021 (Q2-2021), the ANE and MinTIC will initiate the regulation of the frequency bands.

Table 4. Colombia's MinTIC timeline for 5G implementation [37].

\begin{tabular}{|c|c|c|c|c|c|}
\hline $\begin{array}{l}\text { Development } \\
\text { and Publication } \\
\text { of the 5G Plan }\end{array}$ & ANE -MinTIC & ANE-MinTIC & $\begin{array}{l}\text { Communications } \\
\text { Regulation } \\
\text { Commission (CRC) }\end{array}$ & $\begin{array}{c}\text { Analysis of } \\
\text { Frequency Band } \\
\text { Management } \\
\text { Mechanisms }\end{array}$ & MinTIC \\
\hline Q4-2019 & Q2-2020 & Q3-2020 & Q4-2020 & Q2-2021 & Q3-2021 \\
\hline MinTIC & 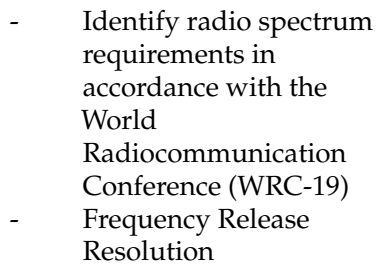 & $\begin{array}{c}\text { Call for the } \\
\text { development of } \\
\text { applications or use } \\
\text { cases in 5G } \\
\text { technology }\end{array}$ & $\begin{array}{l}\text { Consult regulatory } \\
\text { adjustment needs }\end{array}$ & ANE-MinTIC & $\begin{array}{c}3500 \mathrm{MHz} \text { band } \\
\text { allocation. }\end{array}$ \\
\hline
\end{tabular}

Supported by 5G technology and the International Mobile Telecommunications standard 2020 (IMT-2020), it is expected to improve the wireless infrastructure to connect it to the world in Colombian society, generating new ICT (Information and Communication Technologies) markets, in order to reduce the digital divide, and promoting new forms of communication that allow the sharing of content at any time/place, using any device. It also offers new forms of education with access to digital textbooks stored in the cloud, promoting e-learning, e-health, and e-commerce applications. In addition, it will promote energy efficiency in a variety of sectors of the economy, supporting machineto-machine communications in smart grid solutions, video conferencing, logistics, and intelligent transport.

\subsection{G Pilot Tests in Colombia}

The electromagnetic spectrum is a natural resource and public good in Colombia, subject to regulations and laws that guarantee equal access opportunities to avoid monopolies and promote the development and investment of technologies that make use of it [55-57]. In this sense, with the resolution [58], the call for pilot tests of 5G technology was launched to obtain preliminary information and evaluate future challenges under real conditions. In total, 76 expressions of interest were received from more than 52 entities and 24 individuals. 
Figure 3 details the frequency bands requested during the call. The $3.3 \mathrm{GHz}-3.7 \mathrm{GHz}$ band reached the highest number of interested parties (27) for the configuration of future 5G services in Colombia. Nevertheless, there were 56 applications for $\mathrm{mm}-\mathrm{W}$ because they plan to offer $5 \mathrm{G}$ technology services that demand high bandwidth, low latency, and a high data rate. Due to $\mathrm{mm}-\mathrm{W}$ having high bandwidth, they can accommodate more connected devices in a 5G deployment, offering not only greater speed but also better quality of service.

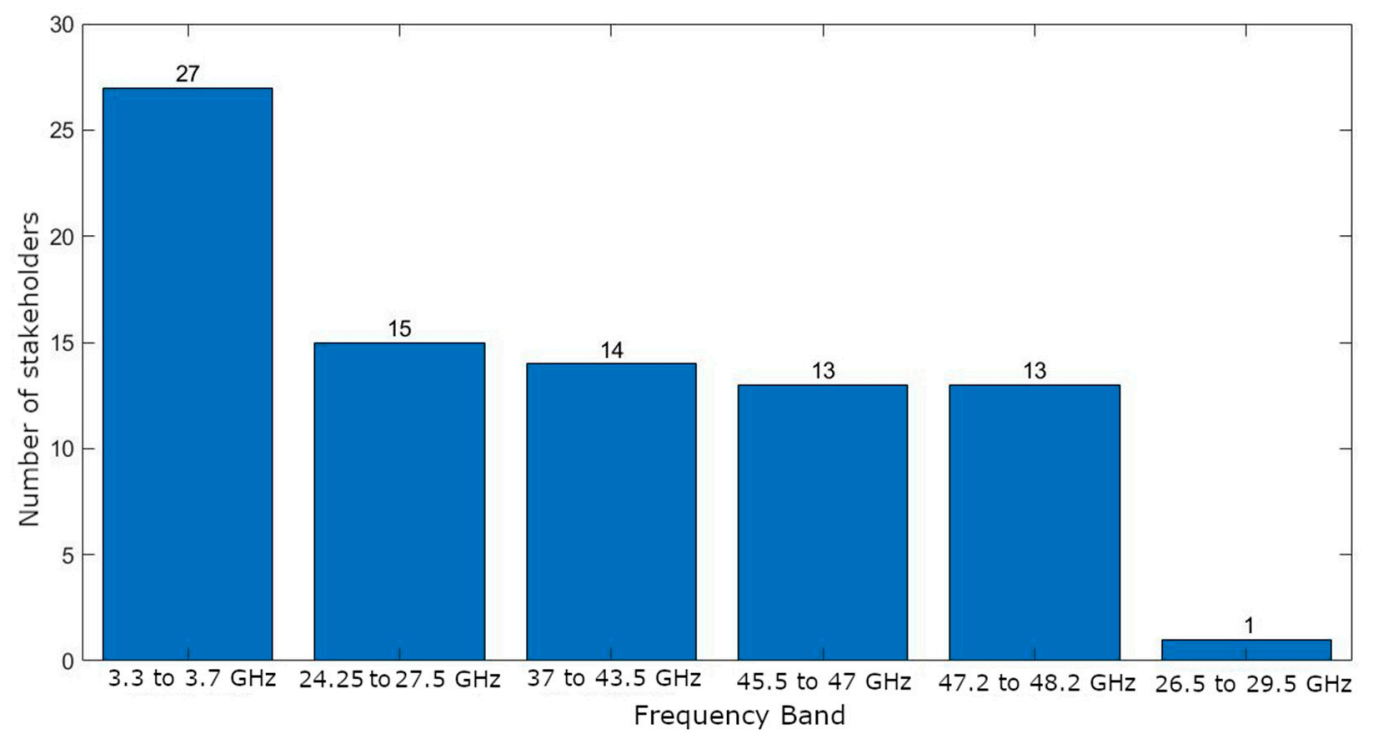

Figure 3. Number of stakeholders by frequency bands [58].

Permits for the radio spectrum use were granted for technical tests or approval of equipment for a period of 6 months, with the possibility of extending this period once for a further 6 months.

The pilot tests of 5G mobile technology in Colombia allow MinTIC, the ANE, and the CRC (Communications Regulation Commission) to have greater knowledge of aspects related to the efficient use of frequencies for the deployment of $5 \mathrm{G}$ networks and services, as a reference for possible measures linked to the deployment of these networks. The permits for the 5G pilot tests are not commercial in nature and are issued under the principle of non-interference without representing a risk of affecting sensitive communications, such as aeronautical radio navigation, radio astronomy, search/rescue operations, and mobile communications, among others. The resolution [59] established the schedule for requesting pilot test permits and setting up test beds in the field of $5 \mathrm{G}$ mobile technology and use cases in the following frequency bands: $3.3-3.7 \mathrm{GHz}, 24.25-27.5 \mathrm{GHz}, 37-43.5 \mathrm{GHz}, 45.5-47 \mathrm{GHz}$, and $47.2-48.2 \mathrm{GHz}$ [56], which was modified in its dates (Table 5) by the resolution [60] due to the COVID-19 pandemic. 
Table 5. Chronology of the 5G network pilot testing process in Colombia.

\begin{tabular}{cc}
\hline \multicolumn{1}{c}{ Activity } & Date \\
\hline Opening of the call process & As of the issuance of this resolution \\
\hline $\begin{array}{c}\text { Closing reception of applications } \\
\begin{array}{c}\text { Evaluation of applications, frequency studies, } \\
\text { and requests for clarification }\end{array}\end{array}$ & 29 May 2020 \\
\hline $\begin{array}{c}\text { Publication of the evaluation report on } \\
\text { applications submitted }\end{array}$ & 19 June 2020 \\
\hline $\begin{array}{c}\text { Issuance of resolutions to grant permission to } \\
\text { use the radio spectrum for 5G technical tests }\end{array}$ & 23 to 30 June 2020 \\
\hline Publication of the assignment report & 1 July 2020 \\
\hline
\end{tabular}

Figure 4 sets out the number of entities associated with future 5G-related projects that responded to the call [56]. Smart Cities was the one with the highest demand. A smart city is first and foremost a connected city, which assumes connectivity without limitations for things as well as people, with 5G being the standard upon which a connected city must be built in order to efficiently manage security, transport, or health resources, improving the quality of life of citizens in terms of economy, access to services, and territorial sustainability.

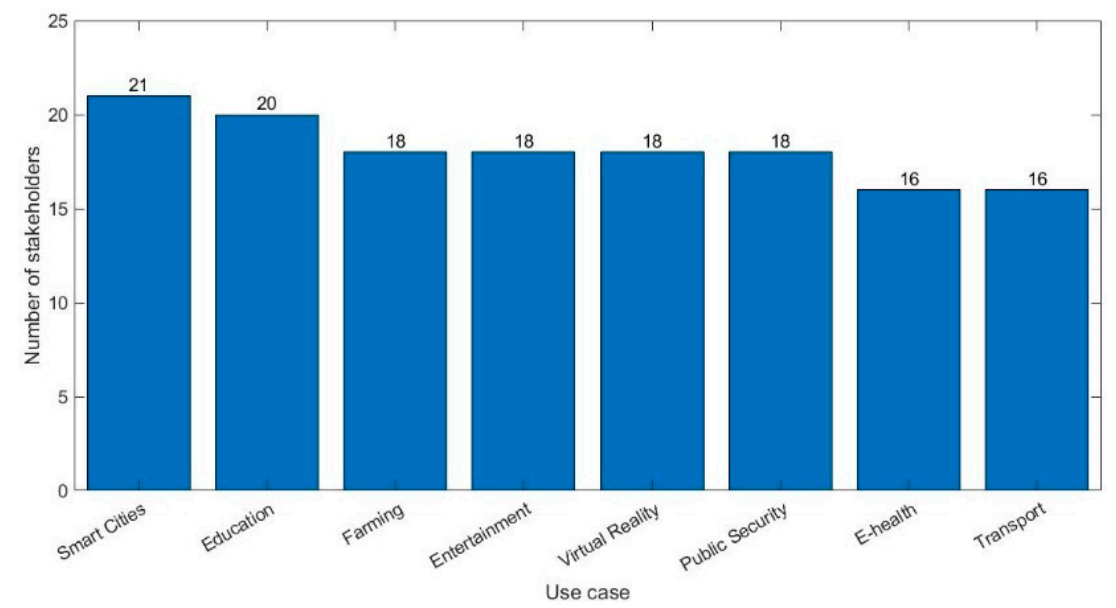

Figure 4. Number of stakeholders with respect to use cases [58].

The licensed period for the $3.5 \mathrm{GHz}$ band will be 20 years, extendable for an additional 20 years [61]. At the same time, MinTIC is focusing on the transition from $2 \mathrm{G}$ and $3 \mathrm{G}$ networks to $4 \mathrm{G}$ [62], expanding coverage in 3658 locations in Colombia's 32 departments. In addition, the MinTIC continues to make progress in 5G trials by granting permits to six companies to deploy $425 \mathrm{G}$ pilots test in Bogotá, Medellín, Cali, Barrancabermeja, and Tolú [63] by running the tests for mobile phone networks in the 3500-3600 MHz frequency range [64]. Regarding 5G pilot tests, the telephone operator Movistar was conducted a trial at the Central Military Hospital in Bogotá to support ICU-COVID-19 patient care through videoconferencing equipment and rooms for medical remote consultations supported by a medical trolley and tele-triage. In this test, they achieved a latency of less than 10 milliseconds and offer a throughput of 1.62 Gbps downlink (DL) and $176 \mathrm{Mbps}$ uplink (UL) with an outdoor node in the $3.5 \mathrm{GHz}$ band, plus a $5 \mathrm{G}$ Core $[65,66]$. Mobile operator Claro, in its private $5 \mathrm{G}$ network trial in the $3.5 \mathrm{GHz}$ band at the Plaza Claro shopping centre in Bogotá, achieved throughput of up to $864 \mathrm{Mbps}$ in Download and $103 \mathrm{Mbps}$ in Upload [67-69] using the 3X scenario of the model 3GPP 5G Non-StandAlone [70]. In relation to the millimeter band, the company Claro in January 2018 carried out a demonstration in Colombia in the $28 \mathrm{GHz}$ band reaching throughput of $10 \mathrm{Gbps}$ and latencies of less than 1 
millisecond within the controlled environment of a laboratory [71]. In July of the same year, the mobile operator Telefonica and Ericsson reached throughput between 27 and $31 \mathrm{Gbps}$ with latencies of $5 \mathrm{~ms}$ in the $28 \mathrm{GHz}$ band at Ericsson's facilities in Bogotá [54,72,73].

In the case of the millimeter bands for Colombia, they are expected to be released for 5G use from 2027 (See Table 6), being valuable until the experiences of other countries in the Latin American region. For example, Ericsson's 5G network deployments, working in the $28 \mathrm{GHz} \mathrm{mm}-\mathrm{W}$ band with beamforming functionalities in base station antennas, achieve coverage of $300-400 \mathrm{~m}^{2}$ in urban areas and up to $2 \mathrm{~km}$ in rural areas in Puerto Rico. These speeds vary inversely with the distance to the base station, fluctuating by approximately between $50 \mathrm{Mbps}$ (at $2 \mathrm{~km}$ from the base station) and $2 \mathrm{Gbps}$ (at 50 metres from the base station with line of sight-LOS). Here, mobile terminals make use of Dynamic Spectrum Sharing [74] so that the millimetre band used interacts with other bands of lower frequency, but with better signal strength quality and lower latency, in order to guarantee better speed rates.

\subsection{Current Situation and Future Deployment}

The ANE is the entity in charge of advising the Ministry of Information Technologies and Communications in the design and formulation of policies, plans, and programmes related to the radio spectrum [75]. Reported in August 2020 that the $26 \mathrm{GHz}$ and $38 \mathrm{GHz}$ millimetre bands would be available from 2027 and 2028, respectively, the $3500 \mathrm{MHz}$ band in the third quarter of 2021, while the $700 \mathrm{MHz}, 1900 \mathrm{MHz}, 2500 \mathrm{MHz}$, and $3500 \mathrm{MHz}$ bands for the deployment and provision of 5G terrestrial mobile services in Colombia before the end of the current national government (before September 2022) [63,76]. This information is summarized in Table 6. The $3500 \mathrm{MHz}$ band is the "fundamental enabler" for the commercial deployment of 5G because it is the globally cleared (harmonised) band for this purpose [77]. Colombia has $400 \mathrm{MHz}$ released between the ranges $3300 \mathrm{MHz}-3700 \mathrm{MHz}$ in the $3.5 \mathrm{GHz}$ [61] with a suggested GSA (Global Mobile Suppliers Association) block of 80 or $100 \mathrm{MH}$ necessary for each operator to maximize efficiency and affordability in the first phase of deployment [77]. This band, belonging to the C-band for $5 \mathrm{G}(3300 \mathrm{MHz}-4200 \mathrm{MHz}$ ), will be auctioned in the third quarter of 2021 (Q3-2021). Therefore, Colombia continues to research on $5 \mathrm{G}$ before its launch for commercial use, following similar road maps to other countries in the world, as shown in Figure 5.

It is estimated by $5 \mathrm{G}$ operators that, in its commercial introduction, the radio access network in Colombia will take advantage of part of the elements of the $4 \mathrm{G}$ network to reduce costs such as by reusing basebands. In the case of Ericsson-branded BBUs, they could be reused if they are no more than 5 years old, leaving most of the capital investment in the radio and spectrum without the need to upgrade the entire network. 


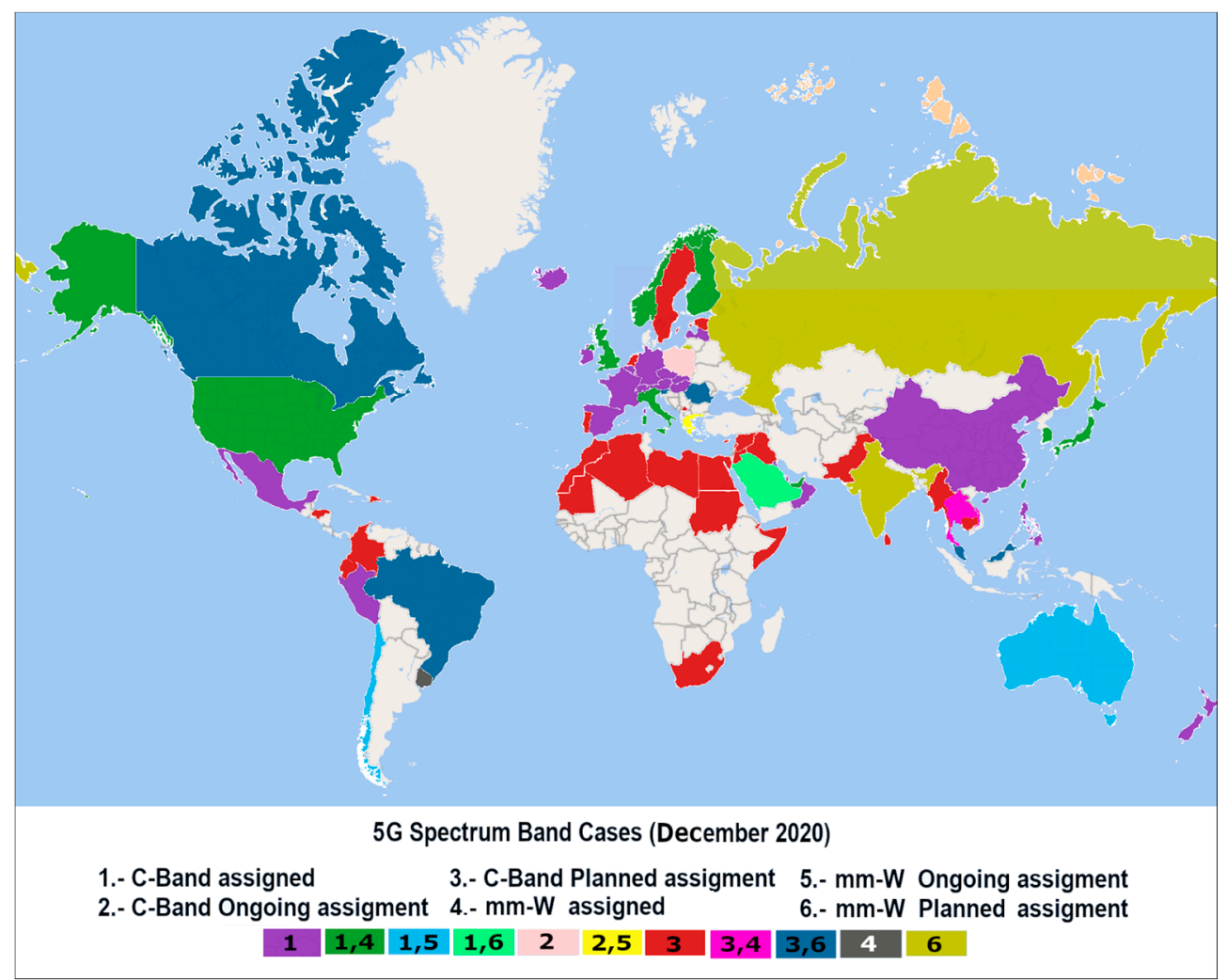

Figure 5. C-Band for $5 \mathrm{G}(3300 \mathrm{MHz}-4200 \mathrm{MHz})$ and mm-W band for $5 \mathrm{G}$ at $26 / 28 \mathrm{GHz}$ situation in the worldwide map by December 2020 for 5G [78].

Most of the mobile operators in both Colombia and Latin America, for the initial phase of the 5G network commercial deployment, estimate that it will be almost 100\% D-RAN. However, they envision C-RAN for particular cases, such as in industrial areas, in a small percentage of the 5G network. The use of C-RAN in Colombia and Latin America is in its beginnings and is currently more inefficient than D-RAN in terms of energy resource consumption and processing. Tests carried out in Ericsson laboratories reveal that moving distributed BBU functions to COTS X86 ("Commercial of the Shelf") type servers, which are currently the resources available on the market in data centres, are not yet $100 \%$ optimised to run telecommunications applications. Then, more servers are required and, therefore, greater energy consumption to match the capacity of the BBU are necessary, which needs $1.5 \mathrm{U}$ (rack unit) per site to process several technologies at the same time. Another scenario is to make BBU-Hotels or BBU-Pool, but there are limitations on the distance of the Fronthaul (10 to $15 \mathrm{~km}$ ) between the RRH (remote radio head), and the BBU [79] to ensure a latency of fewer than 100 microseconds and a minimum channel capacity of $10 \mathrm{Gbps}[80,81]$. These latency and throughput rates are different from the access network we have today, and we should expect a higher cost per access point. Therefore, it is not a recommended alternative for mass deployments of C-RANs at this time. 
Table 6. Details of 5G frequency bands in Colombia.

\begin{tabular}{|c|c|c|c|c|}
\hline $\begin{array}{c}\text { Band } \\
\text { Frequency } \\
\text { (MHz) }\end{array}$ & $\begin{array}{c}\text { Total Free } \\
\text { Spectrum in } \\
\text { Band (MHz) }\end{array}$ & $\begin{array}{c}\text { Spectrum to } \\
\text { be Assigned } \\
\text { Per Block } \\
\text { (MHz) }\end{array}$ & $\begin{array}{c}\text { Planned Auction } \\
\text { Year/Available Band }\end{array}$ & Source \\
\hline 700 & 10 & 10 & $\begin{array}{l}\text { Before September } 2022 \\
\text { (Auction). } \\
\text { For } 4 G \text { use, most of this } \\
\text { frequency band was } \\
\text { licensed in December } \\
2019 \text {. }\end{array}$ & {$[62,82-86]$} \\
\hline 1900 & 5 & 5 & $\begin{array}{c}\text { Before September } 2022 \\
\text { (Auction). } \\
\text { For } 4 \mathrm{G} \text { use, most of this } \\
\text { frequency band was } \\
\text { licensed in December } \\
2019 .\end{array}$ & {$[62,82-86]$} \\
\hline 2500 & 20 & 10 & $\begin{array}{c}\text { Before September } 2022 \\
\text { (Auction). } \\
\text { For } 4 \mathrm{G} \text { use, most of this } \\
\text { frequency band was } \\
\text { licensed in December } \\
2019 .\end{array}$ & $\begin{array}{c}{[62,81,83,84,} \\
86]\end{array}$ \\
\hline 3500 & 400 & 80 or 100 & $\begin{array}{c}\text { Third quarter of } 2021 \\
\text { (Auction). }\end{array}$ & {$[87,88]$} \\
\hline 26,000 & 1000 & 56 or 112 & Available in 2027 & {$[61,87]$} \\
\hline 38,000 & 1000 & $\begin{array}{l}\text { There are no } \\
\text { ITU-approved } \\
\text { channelisa- } \\
\text { tions for this } \\
\text { frequency } \\
\text { band }\end{array}$ & Available in 2028 & [87] \\
\hline
\end{tabular}

\section{Conclusions}

Colombia is planning to provide commercial service of the 5G mobile phone network from the last quarter of 2021 (4Q-2021) to align with the plans of other countries. In a similar way to other European and American countries, pilot test phases were began to determine the performance and robustness of the tested $5 \mathrm{G}$ networks.

To understand the efforts, costs, and difficulties that a full deployment of 5G mobile networks may involve to all stakeholders, we analysed some of the most relevant issues and characteristics behind 5G. All this contributes toward achieving its real penetration, to improve the coverage and performance for the next generation of connected applications, such as the Internet of Things, Telemedicine, and Industry 4.0, among others.

Generally speaking, a wide 5G deployment in higher and lower frequency bands by use of Dynamic Spectrum Sharing improves the access and coverage to mobile networks for sparse and dense population areas. For this reason, to mitigate the attenuation in $\mathrm{mm}-\mathrm{W}$ band, when there is no free line of sight over short and long distances, a combination of Dynamic Spectrum Sharing, mMIMO system, and beamforming functionalities can be used to give a better connectivity experience.

Finally, we put a spotlight on the stakeholders, future use cases, and advance in Colombian implementation, which may serve as a point of reference for researchers in the area of telecommunications, specifically the deployment of $5 \mathrm{G}$ mobile networks with other countries in the world.

Author Contributions: Conceptualization, M.D., J.A.H.-T., F.G.-M., D.C.-P. and A.C.-P. Data curation, D.C.-P., J.A.H.-T., and J.M.-L. Formal analysis, D.C.-P., M.D., J.A.H.-T., F.G.-M., and A.C.-P. Funding acquisition, D.C.-P. and A.C.-P. Investigation, D.C.-P., M.D., J.A.H.-T., F.G.-M., A.C.C.-C., and A.C.-P. 
Methodology, D.C.-P., M.D., J.A.H.-T., J.M.-L., A.C.C.-C., and A.C.-P. Project administration, D.C.-P., M.D., and A.C.-P. Resources, D.C.-P. Software, D.C.-P. and A.C.-P. Supervision, M.D., J.A.H.-T., and F.G.-M. Validation, M.D., J.A.H.-T., A.C.C.-C., and A.C.-P. Writing-original draft, D.C.-P. and A.C.-P. Writing-review \& editing, J.A.H.-T., D.C.-P. and A.C.-P. All authors have read and agreed to the published version of the manuscript.

Funding: This research received support from the AUIP (Iberoamerican University Association for Postgraduate Studies).

Acknowledgments: The authors would like to thank the following members of Ericsson and Nokia Company for their valuable technological support in relation to the deployment of $5 \mathrm{G}$ networks in Colombia and Latin America. To Ericsson Company: Fabian Monge, Head of Networks \& Managed Services Sales LATAM North-Ericsson, Andrés Quintero Arango, Country Manager ColombiaEricsson, Camilo Beltrán, RAN Sales Domain Manager-Ericsson, Tatiana Dimian, Technical \& Solution Sales Colombia-Ericsson. To Nokia Company: Juan Gabriel Mariño Pedroza, Presales Director \& Business Development Colombia-Nokia.

Conflicts of Interest: The authors declare no conflict of interest.

\section{References}

1. Robaei, M.; Akl, R. Examining Spatial Consistency for Millimeter-Wave Massive MIMO Channel Estimation in 5G-NR. IEEE Int. Conf. Consum. Electron. (ICCE) 2020, 9042983. [CrossRef]

2. Sun, L.; Li, Y.; Zhang, Z.; Feng, Z. Wideband 5G MIMO Antenna with Integrated Orthogonal-Mode Dual-Antenna Pairs for Metal-Rimmed Smartphones. IEEE Trans. Antennas Propag. 2019, 68, 2494-2503. [CrossRef]

3. Chataut, R.; Akl, R.; Robaei, M. Accelerated and Preconditioned Refinement of Gauss-Seidel Method for Uplink Signal Detection in 5G Massive MIMO Systems. Annu. Comput. Commun. Workshop Conf. (CCWC) 2020, 83-89. [CrossRef]

4. Khalid, M.; Naqvi, S.I.; Hussain, N.; Rahman, M.; Fawad; Mirjavadi, S.S.; Khan, M.J.; Amin, Y. 4-Port MIMO Antenna with Defected Ground Structure for 5G Millimeter Wave Applications. Electronics 2020, 9, 71. [CrossRef]

5. Albataineh, Z.; Hayajneh, K.; Salameh, H.B.; Dang, C.; Dagmseh, A. Robust massive MIMO channel estimation for 5G networks using compressive sensing technique. AEU Int. J. Electron. Commun. 2020, 120, 153197. [CrossRef]

6. Sakai, M.; Kamohara, K.; Iura, H.; Nishimoto, H.; Ishioka, K.; Murata, Y.; Yamamoto, M.; Okazaki, A.; Nonaka, N.; Suyama, S.; et al. Experimental Field Trials on MU-MIMO Transmissions for High SHF Wide-Band Massive MIMO in 5G. IEEE Trans. Wirel. Commun. 2020, 19, 2196-2207. [CrossRef]

7. Ibrahim, A.A.Z.; Hashim, F.; Noordin, N.K.; Sali, A.; Navaie, K.; Fadul, S.M.E. Heuristic Resource Allocation Algorithm for Controller Placement in Multi-Control 5G Based on SDN/NFV Architecture. IEEE Access 2021, 9, 2602-2617. [CrossRef]

8. Wang, H.; Zhang, R.; Luo, Y.; Yang, G. Compact Eight-Element Antenna Array for Triple-Band MIMO Operation in 5G Mobile Terminals. IEEE Access 2020, 8, 19433-19449. [CrossRef]

9. Elshirkasi, A.M.; Al-Hadi, A.A.; Soh, P.J.; Mansor, M.F.; Khan, R.; Chen, X.; Akkaraekthalin, P. Performance Study of a MIMO Mobile Terminal with Upto 18 Elements Operating in the Sub-6 GHz 5G Band with User Hand. IEEE Access 2020, 8, 28164-28177. [CrossRef]

10. Carrera, D.F.; Vargas-Rosales, C.; Azpilicueta, L.; Galaviz-Aguilar, J.A. Comparative study of channel estimators for massive MIMO 5G NR systems. IET Commun. 2020, 14, 1175-1184. [CrossRef]

11. Ribeiro, C.; Gomes, R.; Duarte, L.; Hammoudeh, A.; Caldeirinha, R.F. Multi-Gigabit/s OFDM real-time based transceiver engine for emerging 5G MIMO systems. Phys. Commun. 2020, 38, 100957. [CrossRef]

12. Kim, J.; Sung, M.; Cho, S.-H.; Won, Y.-J.; Lim, B.-C.; Pyun, S.-Y.; Lee, J.-K.; Lee, J.H. MIMO-Supporting Radio-Over-Fiber System and its Application in mmWave-Based Indoor 5G Mobile Network. J. Light. Technol. 2020, 38, 101-111. [CrossRef]

13. Usami, M. New World Explored by 5G. In Proceedings of the 2020 IEEE International Conference on Consumer Electronics (ICCE), Las Vegas, NV, USA, 4-6 January 2020.

14. Popovski, P.; Trillingsgaard, K.F.; Simeone, O.; Durisi, G. 5G Wireless Network Slicing for eMBB, URLLC, and mMTC: A Communication-Theoretic View. IEEE Access 2018, 6, 55765-55779. [CrossRef]

15. Hui, H.; Ding, Y.; Shi, Q.; Li, F.; Song, Y.; Yan, J. 5G network-based Internet of Things for demand response in smart grid: A survey on application potential. Appl. Energy 2020, 257, 113972. [CrossRef]

16. Husenovic, K.; Bedi, I.; Maddens, S.; Bozsoki, I.; Karyabwite, D.; Sundberg, N.; Maniewicz, M. Setting the Scene for 5G: Opportunities \& Challenges. International Telecommunication Union. 2018. Available online: https://www.itu.int/dms_pub/ itu-d/opb / pref/D-PREF-BB.5G_01-2018-PDF-E.pdf (accessed on 21 June 2020).

17. Chaudhary, P.; Kumar, A.; Yadav, A. Pattern diversity MIMO 4G AND 5G wideband circularly polarized antenna with integrated LTE band for mobile handset. Prog. Electromagn. Res. M 2020, 89, 111-120. [CrossRef]

18. Chen, W.; Lv, G.; Liu, X.; Wang, D.; Ghannouchi, F.M. Doherty PAs for 5G Massive MIMO: Energy-Efficient Integrated DPA MMICs for Sub-6-GHz and mm-Wave 5G Massive MIMO Systems. IEEE Microw. Mag. 2020, 21, 78-93. [CrossRef] 
19. Singh, A.; Saavedra, C.E. Fluidically Reconfigurable MIMO Antenna with Pattern Diversity for Sub-6-GHz 5G Relay Node Applications. Can. J. Electr. Comput. Eng. 2020, 43, 92-99. [CrossRef]

20. Xu, Z.; Deng, C. High-Isolated MIMO Antenna Design Based on Pattern Diversity for 5G Mobile Terminals. IEEE Antennas Wirel. Propag. Lett. 2020, 19, 467-471. [CrossRef]

21. Alkaraki, S.; Gao, Y. mm-Wave Low-Cost 3D Printed MIMO Antennas with Beam Switching Capabilities for 5G Communication Systems. IEEE Access 2020, 8, 32531-32541. [CrossRef]

22. Vojnović, N.M.; Savić, S.V.; Ilić, M.M.; Ilić, A.Ž. Performance Analysis of Low-Cost Printed Antenna Array Elements for 5G LOS-MIMO Arrays at $60 \mathrm{GHz}$. Wirel. Pers. Commun. 2020, 111, 2641-2658. [CrossRef]

23. Barani, I.R.R.; Wong, K.-L.; Zhang, Y.-X.; Li, W.-Y. Low-Profile Wideband Conjoined Open-Slot Antennas Fed by Grounded Coplanar Waveguides for $4 \times 45$ G MIMO Operation. IEEE Trans. Antennas Propag. 2020, 68, 2646-2657. [CrossRef]

24. Kavitha, M.; Shanthi, S.; Beno, A.; Arul Rajan, B.; Sathish, M. Design of $2 \times 2$ MIMO-DRA antenna for $5 \mathrm{~g}$ communication. Int. J. Sci. Technol. Res. 2020, 9, 7025-7029.

25. El Misilmani, H.M.; El-Hajj, A.M. Massive MIMO Design for 5G Networks: An Overview on Alternative Antenna Configurations and Channel Model Challenges. Int. Conf. High Perform. Comput. Simul. (HPCS) 2017, 288-294. [CrossRef]

26. GSMA. 5G Spectrum GSMA Public Policy Position. 2020. Available online: https://www.gsma.com/spectrum/wp-content/ uploads /2020/03/5G-Spectrum-Positions.pdf (accessed on 1 April 2021).

27. Parchin, N.O.; Basherlou, H.J.; Al-Yasir, Y.I.A.; Abdulkhaleq, A.M.; Patwary, M.; Abd-Alhameed, R.A. A New CPW-Fed Diversity Antenna for MIMO 5G Smartphones. Electronics 2020, 9, 261. [CrossRef]

28. Parchin, N.O.; Al-Yasir, Y.I.A.; Basherlou, H.J.; Abd-Alhameed, R.A. A closely spaced dual-band MIMO patch antenna with reduced mutual coupling for 4G/5G applications. Prog. Electromagn. Res. C 2020, 101, 71-80. [CrossRef]

29. Zhang, X.-X.; Ren, A.-D.; Liu, Y. Decoupling methods of MIMO antenna arrays for 5G applications: A review. Front. Inf. Technol. Electron. Eng. 2020, 21, 62-71. [CrossRef]

30. Subbaraj, S.; Kanagasabai, M.; Mohammed, G.N.A.; Palaniswamy, S.K.; Tipparaju, R.R.; Kingsly, S.; Selvam, Y.P. Integrated 4G/5G Multiservice MIMO Antenna for Hand-Held Devices. Wirel. Pers. Commun. 2019, 111, 2023-2043. [CrossRef]

31. Tang, W.; Kang, S.; Zhao, J.; Zhang, Y.; Zhang, X.; Zhang, Z. Design of MIMO-PDMA in 5G mobile communication system. IET Commun. 2020, 14, 76-83. [CrossRef]

32. Tsai, M.-D.; Yang, S.-Y.; Yu, C.-Y.; Chen, P.-Y.; Wu, T.-H.; Hassan, M.; Chen, C.-T.; Wang, C.-W.; Huang, Y.-C.; Hung, L.-H.; et al. 10.3 A 12nm CMOS RF Transceiver Supporting 4G/5G UL MIMO. IEEE Int. Solid State Circuits Conf. (ISSCC) 2020, 176-178. [CrossRef]

33. Larsson, E.G.; Danev, D.; Olofsson, M.; Sorman, S. Teaching the Principles of Massive MIMO: Exploring reciprocity-based multiuser MIMO beamforming using acoustic waves. IEEE Signal Process. Mag. 2017, 34, 40-47. [CrossRef]

34. Zhu, Y.; Chen, Y.; Yang, S. Integration of 5G Rectangular MIMO Antenna Array and GSM Antenna for Dual-Band Base Station Applications. IEEE Access 2020, 8, 63175-63187. [CrossRef]

35. Buzzi, S.; D'Andrea, C.; Zappone, A.; D'Elia, C. User-Centric 5G Cellular Networks: Resource Allocation and Comparison with the Cell-Free Massive MIMO Approach. IEEE Trans. Wirel. Commun. 2020, 19, 1250-1264. [CrossRef]

36. Bjornson, E.; Van Der Perre, L.; Buzzi, S.; Larsson, E.G. Massive MIMO in Sub-6 GHz and mmWave: Physical, Practical, and Use-Case Differences. IEEE Wirel. Commun. 2019, 26, 100-108. [CrossRef]

37. MinTIC. Ministry of Information and Communication Technologies-Mobile Service. Available online: https://www.mintic. gov.co/portal/inicio/Sala-de-Prensa/Noticias/161329:En-mayo-de-2021-954-localidades-de-zonas-rurales-tendran-serviciomovil-4G-anuncia-la-ministra-Karen-Abudinen (accessed on 1 April 2021).

38. Jungnickel, V.; Habel, K.; Parker, M.; Walker, S.; Bock, C.; Riera, J.F.; Marques, V.; Levi, D. Software-defined open architecture for front- and backhaul in $5 \mathrm{G}$ mobile networks. Int. Conf. Transparent Opt. Netw. (ICTON) 2014, 1-4. [CrossRef]

39. Chih-Lin, I.; Huang, J.; Duan, R.; Cui, C.; Jiang, J.; Li, L. Recent Progress on C-RAN Centralization and Cloudification. IEEE Access 2014, 2, 1030-1039. [CrossRef]

40. Intel. Wind an Intel Company-vRAN: The Next Step in Network Transformation. Available online: https://builders.intel.com/ docs/networkbuilders/vran-the-next-step-in-network-transformation.pdf (accessed on 1 April 2021).

41. Lin, Y.; Feng, L.; Li, W.; Zhou, F.; Ou, Q. Stochastic Joint Bandwidth and Computational Allocation for Multi-Users and Multi-Edge-Servers in 5G D-RANs. IEEE Int. Conf. Smart Cloud 2019, 65-70. [CrossRef]

42. Xu, J.; Dziong, Z.; Luxin, Y.; Huang, Z.; Xu, P.; Cabani, A. Intelligent multi-agent based C-RAN architecture for 5G radio resource management. Comput. Networks 2020, 180, 107418. [CrossRef]

43. Mei, H.; Peng, L. Flexible functional split for cost-efficient C-RAN. Comput. Commun. 2020, 161, 368-374. [CrossRef]

44. Keysight. 5G Terms and Acronyms. Available online: https://www.keysight.com/us/en/assets/7018-06171/brochures/5992-2 996.pdf (accessed on 1 April 2021).

45. Gavrilovska, L.; Rakovic, V.; Denkovski, D. From Cloud RAN to Open RAN. Wirel. Pers. Commun. 2020, 113, 1523-1539. [CrossRef]

46. Mendes, J.; Jiao, X.; Garcia-Saavedra, A.; Huici, F.; Moerman, I. Cellular access multi-tenancy through small-cell virtualization and common RF front-end sharing. Comput. Commun. 2019, 133, 59-66. [CrossRef]

47. McKenney, B. Open RAN: Reality or Illusion? Available online: https://www.microwavejournal.com/articles/35108-open-ranreality-or-illusion (accessed on 1 April 2021). 
48. Nokia. Open RAN Explained. Available online: https://www.nokia.com/about-us/newsroom/articles/open-ran-explained/ (accessed on 1 April 2021).

49. Ericsson. Non-Standalone and Standalone: Two Standards-Based Paths to 5G. Available online: https://www.ericsson.com/en/ blog/2019/7/standalone-and-non-standalone-5g-nr-two-5g-tracks (accessed on 1 April 2021).

50. GSMA. 5G Implementation Guidelines. Available online: https://www.gsma.com/futurenetworks/wp-content/uploads/2019 /03/5G-Implementation-Guideline-v2.0-July-2019.pdf (accessed on 1 April 2021).

51. Samsung. 5G Standalone Architecture. Available online: https://images.samsung.com/is/content/samsung/p5/global/ business/networks/insights/white-papers/0107_5g-standalone-architecture/5G_SA_Architecture_Technical_White_Paper_ Public.pdf (accessed on 1 April 2021).

52. Agiwal, M.; Kwon, H.; Park, S.; Jin, H. A Survey on 4G-5G Dual Connectivity: Road to 5G Implementation. IEEE Access 2021, 9 , 16193-16210. [CrossRef]

53. GSMA. 5G Implementation Guidelines: NSA Option 3. Available online: https://www.gsma.com/futurenetworks/wp-content/ uploads /2019/03/5G-Implementation-Guidelines-NSA-Option-3-v2.1.pdf (accessed on 1 April 2021).

54. Constain, S.; Mantilla-Gaviria, I.A.; Rueda-Jiménez, G.C.; Fernanda-Trujillo, L.; Barrera-Medina, J.G.; Thiriat-Tovar, P.E.; UstateBermúdez, A.G.; Triviño-Arbelaez, H.M.; Agudelo-Mora, O.I. Plan 5G-Colombia's Digital Future Belongs to Everyone; Ministry of Information and Communication Technologies of Colombia: Bogota, Colombia, 2019. Available online: https://micrositios. mintic.gov.co/plan_tic_2018_2022/pdf/plan_tic_2018_2022_20191121.pdf (accessed on 1 April 2021).

55. MinTIC. Ministry of Information and Communications - Resolution number 00467 of March 9, 2020. Available online: http: //micrositios.mintic.gov.co/plan_5g/pdf/resolucion_467_2020_temporal_espectro_pruebas.pdf (accessed on 1 April 2021).

56. MinTIC. Ministry of Information and Communications Technology—Resolution number 003209 of 5 December 2019 . Available online: https:/ /www.mintic.gov.co/portal/604/articles-118058_resolucion_3209_2019.pdf (accessed on 1 April 2021).

57. ANE. National Spectrum Agency. Resolution Number 442 of 22 August 2013. Available online: https://normograma.mintic.gov. co/mintic/docs/resolucion_mintic_0963_2019.htm (accessed on 1 April 2021).

58. MinTIC. Ministry of Information and Communications-5G Pilot Expressions of Interest Report. 2020. Available online: http:// micrositios.mintic.gov.co/plan_5g/pdf/informe_manifestaciones_interes_piloto_5Gg_u20200311.pdf (accessed on 1 April 2021).

59. MinTIC. Ministry of Information and Communications-Resolution number 000638 of 1 April 2020. Available online: http: / / micrositios.mintic.gov.co/plan_5g/pdf/resolucion_638.pdf (accessed on 1 April 2021).

60. MinTIC. Ministry of Information and Communications-Resolution number 000722 of 30 April 2020. Available online: https: //micrositios.mintic.gov.co/plan_5g/pdf/resolucion_722.pdf (accessed on 1 April 2021).

61. GSMA. 5G y el Rango 3,3-3,8 GHz en América Latina November 2020. Available online: https://www.gsma.com/spectrum/wpcontent/uploads/2020/11/5G-and-3.5-GHz-Range-in-Latam-Spanish.pdf (accessed on 1 April 2021).

62. MinTIC. Ministry of Information and Communications-Mintic Hopes to Have a $5 \mathrm{G}$ Auction before the End of the Government. Available online: https://mintic.gov.co/portal/inicio/https://www.mintic.gov.co/portal/inicio/Sala-de-Prensa/MinTIC-enlos-Medios/161584:Mintic-espera-tener-una-subasta-5G-antes-que-termine-el-Gobierno (accessed on 1 April 2021).

63. MinTIC. Ministry of Information and Communications-By May 2021, 954 Rural Localities will Have 4G Mobile Service, Announces Minister Karen Abudinen. Available online: https://mintic.gov.co/portal/inicio/Sala-de-Prensa/Noticias/161329: En-mayo-de-2021-954-localidades-de-zonas-rurales-tendran-servicio-movil-4G-anuncia-la-ministra-Karen-Abudinen (accessed on 1 April 2021).

64. MinTIC. Ministry of Information and Communications-Resolution 638 of 1 April 2020. Available online: https://micrositios. mintic.gov.co/plan_5g/pdf/infome_asignacion_5g_2.pdf (accessed on 1 April 2021).

65. Telefonica. Movistar Empresas and Hospital Militar Central Present Second 5G Pilot. Available online: https: / / www.telefonica. co/ver_noticia?id_not=409248143 (accessed on 1 April 2021).

66. HOMIL. Hospital Militar Central-HOMIL and Movistar Empresas Present Second 5G Pilot. Available online: https://www. hospitalmilitar.gov.co/index.php?idcategoria=69906 (accessed on 1 April 2021).

67. Claro. The Deployment of 5G Antennas Continues. Available online: https://www.claro.com.co/institucional/pruebas-5g/ (accessed on 1 April 2021).

68. Claro. 5G Technology in Colombia: Already in Trials. Available online: https://www.claro.com.co/empresas/sectores/noticiasinteres/5g-colombia/ (accessed on 1 April 2021).

69. MinTIC. Ministry of Information and Communications-MinTIC Assigned Spectrum to Claro to Develop 5G Trials for Six Months. Available online: https://www.mintic.gov.co/portal/inicio/Sala-de-Prensa/MinTIC-en-los-Medios/145864:MinTIC-leasigno-espectro-a-Claro-para-desarrollar-pruebas-5G-durante-seis-meses (accessed on 1 April 2021).

70. MinTIC. Ministry of Information and Communications-Resolution 001039 of 23 June 2020. Available online: https://micrositios. mintic.gov.co/plan_5g/pdf/permisos_uso_espectro_piloto_5G.zip (accessed on 1 April 2021).

71. Claro. Claro Expresses Interest in 5G Technology. Available online: https://www.claro.com.co/institucional/tecnologia-5g (accessed on 1 April 2021).

72. MinTIC. Ministry of Information and Communications-In Colombia, 5G Networks Will Be Ready in 2022. Available online: https:/ / www.mintic.gov.co/portal/inicio/Sala-de-Prensa/MinTIC-en-los-Medios/101472:En-Colombia-redes-5G-estaranlistas-en-2022 (accessed on 1 April 2021). 
73. Enter. Telefonica conducted 5G technology trial in Colombia. Available online: https://www.enter.co/empresas/colombiadigital/telefonica-prueba-5g-en-colombia/ (accessed on 1 April 2021).

74. Rebato, M.; Zorzi, M. A Spectrum Sharing Solution for the Efficient Use of mmWave Bands in 5G Cellular Scenarios. IEEE Int. Symp. Dyn. Spectr. Access Netw. (DySPAN) 2018, 1-5. [CrossRef]

75. ANE. National Spectrum Agency-Functions. Available online: http://www.ane.gov.co/Agencia/SitePages/MarcoEstrategico aspx? $\mathrm{p}=1 \& \mathrm{~d}=8]$ (accessed on 1 April 2021).

76. MinTIC. Ministry of Information and Communications-Commercial Roll-Out of 5G Network. Available online: https:// www.mintic.gov.co/portal/inicio/Sala-de-Prensa/MinTIC-en-los-Medios/149152:Colombia-inicia-proceso-para-desplieguecomercial-de-red-5G (accessed on 1 April 2021).

77. GSMA. The WRC Series $3.5 \mathrm{GHz}$ in the 5G Era Preparing for New Services in 3.3-4.2 GHz March 2021. Available online: https://www.gsma.com/spectrum/wp-content/uploads/2021/02/3.5-GHz-for-5G.pdf (accessed on 1 April 2021).

78. GSA. 2020 in Review 5G networks, Spectrum \& Devices (December 2020). Available online: https://gsacom.com/paper/2020-inreview-5g-networks-spectrum-devices/ (accessed on 1 April 2021).

79. Ericsson. Building Efficient Fronthaul Networks Using Packet Technologies. 2020. Available online: https:/ /www.ericsson.com/ en/blog/2020/4/building-efficient-fronthaul-networks-using-packet-technologies (accessed on 1 April 2021).

80. Pérez, G.O.; Hernández, J.A.; Larrabeiti, D. Fronthaul Network Modeling and Dimensioning Meeting Ultra-Low Latency Requirements for 5G. J. Opt. Commun. Netw. 2018, 10, 573-581. [CrossRef]

81. Perez, G.O.; Lopez, D.L.; Hernandez, J.A. 5G New Radio Fronthaul Network Design for eCPRI-IEEE 802.1CM and Extreme Latency Percentiles. IEEE Access 2019, 7, 82218-82230. [CrossRef]

82. MinTIC. Ministry of Information and Communications Technologies-The Spectrum Auction Last December Was Very Clear," Sylvia Constaín. Available online: https:/ / www.mintic.gov.co/portal/inicio/Sala-de-Prensa/Columnas-Ministra-TIC/126186: La-subasta-de-espectro-del-pasado-diciembre-fue-muy-clara-Sylvia-Constain (accessed on 1 April 2021).

83. MinTIC. Ministry of Information and Communication Technologies-Resolution 3078 of 2019. Available online: https:// normograma.mintic.gov.co/mintic/docs/resolucion_mintic_3078_2019.htm (accessed on 1 April 2021).

84. MinTIC. Ministry of Information and Communication Technologies-Resolution 3121 of 2019. Available online: https:// normograma.mintic.gov.co/mintic/docs/resolucion_mintic_3121_2019.htm (accessed on 1 April 2021).

85. Abudinen-Abuchaibe, K.A.; Mantilla-Gaviria, I.A.; Barrera-Medina, J.G.; Ramírez-Echeverry, J.; Rueda-Pepinosa, J.D.; DávilaBarragán, J.A.; González-Cárdenas, G.; Corredor-Forero, H.A.A.; Ustate-Bermúdez, A.G.; Ruiz-Eraso, A.B.; et al. Preliminary Analysis of the Objective Selection Process for the Allocation of Spectrum Use Permits in IMT Bands (2020). Ministry of Information Technologies and Communications of Colombia. Available online: https:/ /www.mintic.gov.co/portal/604/articles146624_resolucion_1322_20200727_soporte_tecnico.pdf (accessed on 1 April 2021).

86. Qualcomm. Global Update on Spectrum for 4G \& 5G. Available online: https://www.qualcomm.com/media/documents / files / spectrum-for-4g-and-5g.pdf (accessed on 1 April 2021).

87. ANE. National Spectrum Agency-Public consultation document on frequency bands available for the future development of International Mobile Telecommunications (IMT) in Colombia, August 2020. Available online: http: / / www.ane.gov.co/Documentos\%20compartidos / ArchivosDescargables/noticias/Consulta\%20p\%C3\%BAblica\%20sobre\%20 las $\% 20$ bandas $\% 20$ disponibles $\% 20$ para $\% 20$ el\%20futuro\%20desarrollo\%20de\%20las\%20IMT\%20en\%20Colombia.pdf (accessed on 1 April 2021).

88. GSMA. 5G Spectrum Positions. 2019. Available online: https://www.gsma.com/latinamerica/wp-content/uploads/2019/03/ 5G-Spectrum-Positions-InfoG.pdf (accessed on 1 April 2021). 